\title{
Fra ketobemidon til morfin eller oksykodon
}

\author{
Ketobemidon (Ketorax) har i flere tiår vært et av de mest brukte intravenøse opioider i Norge. Ved våre syke- \\ hus har vi imidlertid bestemt at bruken av dette preparatet skal opphøre. Årsakene er usikker leveringssitua- \\ sjon, ingen spesielle fordeler fremfor alternative opioider, til dels manglende dokumentasjon og liten inter- \\ nasjonal bruk av preparatet. Vi presenterer her retningslinjer for utfasing av medikamentet ved våre sykehus.
}

I de senere år har det vært betydelig usikkerhet rundt leveringssikkerheten for ketobemidon til injeksjon. Preparatet leveres av kun én produsent og selges nesten ikke utenfor Norge og Sverige. Det har ingen dokumenterte fordeler fremfor riktig valgte alternativer (1-3).

Ved flere norske sykehus har man sluttet å bruke preparatet, likeledes i Danmark, hvor fullstendig utfasing ikke har ført til problemer. I samarbeid med Statens legemiddelverk, RELIS og de lokale legemiddelkomiteene er vi i ferd med å fase ut bruken av ketobemidon ved våre sykehus.

Vi presenterer her kort de nye retningslinjene for våre helseforetak knyttet til utfasingen (ramme 1). Det er viktig å presisere at vi her begrenser oss til å omtale situasjoner der bruk av ketobemidon har vært ansett som riktig og godt begrunnet. Vi vil ikke berøre smertebehandling i sin alminnelighet eller generelle indikasjoner for opioider.

\section{Morfin eller oksykodon?}

Som erstatning for ketobemidon er det ut fra internasjonal dokumentasjon, praksis, medikamenttilgjengelighet og pris naturlig

\section{RAMME 1 \\ Hovedregler for utfasing av ketobemidon ved våre sykehus}

Pasienter som i dag får morfin, fortsetter med morfin

Fremtidige pasienter som det er naturlig å gi morfin, får morfin i tråd med etablerte rutiner

Pasienter som nå får ketobemidon, skal skifte til:

\section{Oksykodon}

- Pasienter med akutt eller meget sterk smerte (f.eks. postoperativ smerte, hvor hurtig intravenøs titrering til adekvat analgetisk effekt er ønskelig)

- Pasienter med nyresvikt

Morfin

- Pasienter hvor stabil, kraftig opioid effekt over lengre tid er ønskelig (f.eks. pasienter med kronisk kreftsmerte og pasienter i palliativ omsorgl

- Pasienter med særlig risiko for misbruk

- Barn å satse på morfin (4) eller oksykodon (5) i de aller fleste tilfeller. Det er ingen store forskjeller mellom disse to preparatene, og

\section{«l de aller fleste til-} feller vil ketobemidon enkelt kunne erstattes med andre opioider»

diskusjonen i noen miljøer har vært om man kan klare seg med morfin som erstatning for nesten alle aktuelle formål.

Morfin er svært godt dokumentert, det er mye brukt og anses ofte som «gullstandarden» når det gjelder intravenøse opioider. Det har et relativt langsomt effektanslag (6) - en fordel når det gjelder kroniske smertepasienter, hvor jevn effekt over tid er ønskelig, og hos misbrukere eller potensielle misbrukere, hvor et «kick» fra en raskt innsettende effekt kan være uheldig (7). Langsomt innsettende effekt kan også innebære en trygghet ved at man ser eventuelle bivirkninger, som søvnighet og respirasjonsdepresjon, utvikle seg over noe tid, slik at man har tid til å tilkalle hjelp og iverksette tiltak.

Morfin har ved gjentatt og/eller langvarig dosering, spesielt ved nyresvikt, den ulempen at opphopning av aktive metabolitter kan skape problemer. Metabolitter kan bidra til uforutsigbar analgetisk effekt eller eksitasjon, eventuelt med kramper (4).

Oksykodon finnes nå bredt og rimelig tilgjengelig som generisk preparat. Man har høstet mye erfaring og dokumentasjon internasjonalt $\mathrm{i}$ alle administrasjonsformer $(8,9)$, mens vi i Norge stort sett kjenner oksykodon til peroral administrasjon. Det har god og forutsigbar absorpsjon på 70-80\% av peroral dose, i motsetning til de fleste andre potente opioider (10). Morfin har, til sammenligning, variabel og lavere absorbsjonsgrad når det gis peroralt (20-50\%) (4).

Til intravenøs bruk har oksykodon vært et hovedpreparat i Finland i flere tiår, og erfaringene derfra er gode (9). Preparatet har små mengder aktive metabolitter, men disse gir ikke kliniske problemer, heller ikke ved nyresvikt. Oksykodon har raskere effekt enn morfin og er derfor lettere å titrere ved akutte, sterke smerter (6). For oksykodon bør man vente inntil 5-6 minutter for å vurdere effekten, mens man med morfin må vente minst 10-20 minutter før man vet om pasienten trenger mer. Hos pasienter med akutt, sterk smerte vil det være enklere å komme raskt til målet med oksykodon enn med morfin.

Titrering av opioider til adekvat effekt er et meget viktig prinsipp ved akutt smertebehandling, fordi den individuelle variasjonen i dosebehov kan være opptil fem ganger mellom pasienter med tilnærmet samme objektive skade eller smerteårsak (6).

Oksykodon er ikke godkjent til barn ( $<20$ år) i Norge, men i USA er det godkjent for barn fra og med 11 års alder. I Finland er det tillatt uten nedre aldersgrense, men i praksis lite brukt intravenøst til barn under to år (11).

\section{Praktisk utfasing}

I de aller fleste tilfeller vil ketobemidon enkelt kunne erstattes med andre opioider (tab 1). Det kan likevel finnes situasjoner der dette ikke oppleves som optimalt for verken behandler eller pasient, for eksempel pasienter med kroniske smerter som etter grundig utprøvning av alternativer fungerer best på ketobemidon. I tillegg kan det være pasienter og behandlere som tidligere har hatt god erfaring med ketobemidon og som derfor vil ha mindre tiltro til alternative preparater.

Ved Oslo universitetssykehus har man allerede i rundt ett år hatt som praksis at morfin, oksykodon og ketobemidon behandles som likeverdige opioider i vedtatt prose-

\begin{tabular}{lcc}
\hline $\begin{array}{l}\text { Tabell } 1 \text { Våre råd for ketobemidonerstat- } \\
\text { ning }{ }^{1} \text { i forskjellige kliniske situasjoner. X = } \\
\text { anbefalt førstevalg, (X) = kan vurderes som } \\
\text { alternativt førstevalg }\end{array}$ & $\begin{array}{c}\text { Oksy- } \\
\text { kodon }\end{array}$ & Morfin \\
\hline Indikasjon & $X$ & $(X)$ \\
Akutt, sterk smerte & $X$ & $(X)$ \\
Postoperativ smerte & $(X)$ & $X$ \\
Kronisk kreftsmerte & $(X)$ & $X$ \\
Palliativ omsorg & $X$ & \\
Pasienter med nyresvikt & $(X)$ & $X$ \\
Barn & & $X$ \\
$\begin{array}{l}\text { Pasienter med } \\
\text { misbruksfare }\end{array}$ & & \\
\hline
\end{tabular}

1 NB! Prosedyren omhandler kun retningslinjer for å erstatte ketobemidon og gir ikke på noen måte uttømmende retningslinjer for smertebehandling 
dyre for all opioid injeksjonsbehandling som skal skje på sengepostene.

Disse tre preparatene kan, for praktiske forhold, anses som tilnærmet ekvipotente, det vil si at man ikke behøver å lære seg nye rutiner knyttet til hvor mange milligram man skal gi i forskjellige situasjoner. Imidlertid må den enkelte behandler være oppmerksom på at de leveres i forskjellige styrker, slik at intravenøse opioider alltid skal doseres i milligram.

Ketobemidon vil utgå fra alle faste rutiner og prosedyrer ved våre sykehus. Så lenge preparatet kan skaffes vil det ikke være noe forbud mot å bruke det i spesielle situasjoner, men bruk skal begrunnes og journalføres for den enkelte pasient.

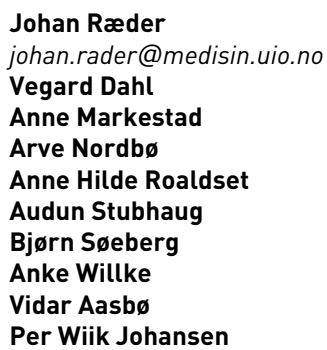

Johan Ræder (f. 1954) er professor og fagansvarlig overlege ved Avdeling for anestesiologi ved Oslo universitetssykehus. Han er medlem av legemiddelkomiteen ved sykehuset. Forfatter har fylt ut ICMJE-skjemaet og oppgir ingen interessekonflikter.

Vegard Dahl (f. 1955) er professor og avdelingssjef ved Anestesiavdelingen, Akershus universitetssykehus.

Forfatter har fylt ut ICMJE-skjemaet og oppgir ingen interessekonflikter.

Anne Markestad (f. 1955) er cand.pharm. og rådgiver for forsyningssikkerhet, Sykehusapotekene HF og Sykehusapoteket Oslo universitetssykehus, Ullevål.

Forfatter har fylt ut ICMJE-skjemaet og oppgir ingen interessekonflikter.
Arve Nordbø (f. 1965) er spesialist i anestesiologi og overlege ved Avdeling for anestesiologi, Sykehuset i Vestfold.

Forfatter har fylt ut ICMJE-skjemaet og oppgir ingen interessekonflikter.

Anne Hilde Roaldset (f. 1954) er spesialist i anestesiologi, har godkjent kompetanseområde palliativ medisin, overlege ved Seksjon lindrende behandling, Avdeling for kreftbehandling, Oslo universitetssykehus

Forfatter har fylt ut ICMJE-skjemaet og oppgir ingen interessekonflikter.

Audun Stubhaug (f. 1958) er professor i anestesiologi ved Universitetet i Oslo og leder av Avdeling for smertemedisin i Akuttklinikken, Oslo universitetssykehus.

Forfatter har fylt ut ICMJE-skjemaet og oppgir ingen interessekonflikter.

Bjørn Søeberg (f. 1963) er spesialist i anestesi og overlege ved Anestesi- og intensivavdelingen ved Bærum sykehus. Han har det medisinske ansvaret for akutt smerteteam.

Forfatter har fylt ut ICMJE-skjemaet og oppgir ingen interessekonflikter.

Anke Willke (f. 1964) er spesialist i anestesiologi og leder av Palliativt avsnitt, Akershus universitetssykehus.

Forfatter har fylt ut ICMJE-skjemaet og oppgir ingen interessekonflikter.

Vidar Aasbø (f. 1955) er dr.med., spesialist i anestesiologi og seksjonsoverlege ved Smerteseksjonen ved Sykehuset Østfold.

Forfatter har fylt ut ICMJE-skjemaet og oppgir ingen interessekonflikter.

Per Wiik Johansen (f. 1956) er dr.med. og spesialist i klinisk farmakologi. Han er seksjonsoverlege ved Seksjon for legemiddelkomité og -sikkerhet, Avdeling for farmakologi, og er leder av legemiddelkomiteen ved Oslo universitetssykehus

Forfatter har fylt ut ICMJE-skjemaet og oppgir ingen interessekonflikter.

\section{Litteratur}

1. Tamsen A, Bondesson U, Dahlström B et al. Patientcontrolled analgesic therapy, Part III: pharmacokinetics and analgesic plasma concentrations of ketobemidone. Clin Pharmacokinet 1982: 7: 252-65.

2. Raeder JC, van der Linden J, Breivik H. Premedication for day-case surgery: double-blind comparison of ketobemidone + dimethylaminodiphenylbuten $(A-29)$ and morphine + scopolamine. Acta Anaesthesiol Scand 1986: 30: 502-6.

3. Al-Shurbaji A, Tokics L. The pharmacokinetics of ketobemidone in critically ill patients. Br J Clin Pharmacol 2002: 54: 583-6.

4. Rygnestad T, Slørdal L. Morfin, petidin eller ketobemidon ved akutt smerte - er det forskjeller av betydning? Tidsskr Nor Lægeforen 2000; 120: 2548-9.

5. Kalso E. Oxycodone. J Pain Symptom Manage 2005: 29 (suppl): S47-56.

6. Lenz H, Sandvik L, Qvigstad E et al. A comparison of intravenous oxycodone and intravenous morphine in patient-controlled postoperative analgesia after laparoscopic hysterectomy. Anesth Analg 2009: 109: 1279-83

7. Kringsholm B, Kaa E, Steentoft A et al. Deaths among drug addicts in Denmark in 1987-1991. Forensic Sci Int 1994; 67: 185-95.

8. Leow KP, Cramond T, Smith MT. Pharmacokinetics and pharmacodynamics of oxycodone when given intravenously and rectally to adult patients with cancer pain. Anesth Analg 1995; 80: 296-302

9. Olkkola KT, Kontinen VK, Saari TI et al. Does the pharmacology of oxycodone justify its increasing use as an analgesic? Trends Pharmacol Sci 2013; 34: $206-14$

10. Riley J, Eisenberg E, Müller-Schwefe G et al. Oxycodone: a review of its use in the management of pain. Curr Med Res Opin 2008; 24: 175-92.

11. Jylli $L$, Lundeberg $S$, Langius-Eklöf $A$ et al. Comparison of the analgesic efficacy of ketobemidone and morphine for management of postoperative pain in children: a randomized, controlled study. Acta Anaesthesiol Scand 2004: 48: 1256-9

Mottatt 7.6. 2016, første revisjon innsendt 13.9. 2016, godkjent 13.9. 2016. Redaktør: Ketil Slagstad.

Publisert først på nett. 